\title{
Study of optical transmittance of photocatalytic titanium dioxide films deposited by radiofrequency magnetron sputtering
}

\author{
Estudo da transmitância óptica dos filmes de dióxido de titânio \\ fotocatalítico depositados por "magnetron sputtering" usando \\ radiofrequência
}

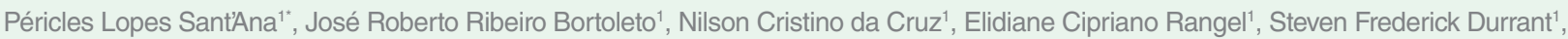
Sofia Azevedo², Carina Isabel S. Simões ${ }^{2}$, Vasco Teixeira²

\begin{abstract}
The optical transmittance of titanium oxide $\left(\mathrm{TiO}_{2}\right)$ films in the ultraviolet-visible region were studied in this work. Such films have possible application in photocatalysis at room temperature. Among many candidates for photocatalysts, $\mathrm{TiO}_{2}$ is practically the only material suitable for industrial use at present. This is because $\mathrm{TiO}_{2}$ has the most efficient photoacatalysis, the highest stability and the lowest cost. Photochemical reactions include the photoinduced redox reactions of adsorbed substances, or the photoinduced hydrophilic conversion of $\mathrm{TiO}_{2}$ itself. Polyethylene terephthalate (PET) was chosen as the substrate because of its flexibility, high transmission in visible light and low cost. Glass blades were used as substrates for $\mathrm{TiO}_{2}$ films for analysis by optical transmittance spectroscopy. The experimental results show that the $\mathrm{TiO}_{2}$ films deposited on glass were associated with the anatase phase with a [0 04 4] preferred orientation. Ultraviolet near infrared spectroscopy revealed the high transmittance of the films in visible light and high absorption in the ultra-violet region under most deposition conditions.
\end{abstract}

Keywords: $\mathrm{TiO}_{2}$, RF sputtering, Optical properties, Photocatalysis.

\section{RESUMO}

A transmitância óptica de filmes de dióxido de titânio $\left(\mathrm{TiO}_{2}\right)$ na região ultravioleta-visível foi estudada neste trabalho. Tais filmes têm possível aplicação em fotocatálise à temperatura ambiente. Entre muitos candidatos a fotocatalisadores, o $\mathrm{TiO}_{2}$ é praticamente $\mathrm{o}$ único material adequado para uso industrial no momento. Isso ocorre porque o $\mathrm{TiO}_{2}$ possui a foto catalise mais eficiente, a maior estabilidade e o menor custo. As reações fotoquímicas incluem as reações de oxireduçao fotoinduzidas de substâncias adsorvidas ou a conversão hidrofílica fotoinduzida do $\mathrm{TiO}_{2}$ em si. O tereftalato de polietileno (PET) foi escolhido como substrato devido à sua flexibilidade, alta transmissão na luz visível e baixo custo. Laminas de vidro foram utilizados como substratos para os filmes de $\mathrm{TiO}_{2}$ para análise por espectroscopia de transmitância óptica. Os resultados experimentais mostram que os filmes de $\mathrm{TiO}_{2}$ depositados no vidro foram associados à fase anatase com uma orientação preferencial em [0 0 4]. A espectroscopia de absorção no infravermelho revelou alta transmitância dos filmes sob luz visível e alta absorção na região ultravioleta sob a maioria das condições de deposição.

Palavras-chave: $\mathrm{TiO}_{2}$, RF "sputtering", Propriedades ópticas, fotocatálise.

\footnotetext{
1.Universidade Estadual Paulista - Câmpus Experimental de Sorocaba - Laboratório de Plasmas Tecnológicos - Sorocaba (SP), Brazil. 2.Universidade do Minho - Departamento de Física - Laboratório de Filmes Finos para a Electrónica - Braga, Portugal. 


\section{INTRODUCTION}

Titanium dioxide $\left(\mathrm{TiO}_{2}\right)$ is an attractive material because of its outstanding physical and chemical properties ${ }^{1,2}$. Various methods of $\mathrm{TiO}_{2}$ film deposition have recently been investigated, including pulsed laser deposition (PLD) ${ }^{3}$, atmospheric dielectric barrier discharge ${ }^{4,6}$ and plasma enhanced chemical vapor deposition (PECVD) $)^{7,8}$.

Although PECVD has many advantages, such as high purity and the easy control of reaction parameters ${ }^{9}$, it is usually performed in high-vacuum environments or requires high temperatures for which the installation costs and the energy requirements are high. The optimal vacuum system parameters for obtaining titanium oxide thin films have been studied since $1972^{10}$. The use of sputtering technique to deposit photocatalytic thin films has been reported ${ }^{11}$. Among the various semiconductors employed, $\mathrm{TiO}_{2}$ is the most preferred material for the photocatalytic process ${ }^{12}$.

Recent studies reveal excellent $\mathrm{TiO}_{2}$ photocatalytic stability ${ }^{13}$. Another advantage is obtained when $\mathrm{TiO}_{2}$ films present high crystallinity, which influences the charge carrier lifetime, and improves photocatalytic activity ${ }^{14}$. The performance of these films in such technologies strongly depends on the $\mathrm{TiO}_{2}$ polymorphic phase employed: rutile, anatase or brookite. Anatase exhibits advantages over rutile for catalysis, photocatalysis and solar cell applications ${ }^{15}$. Some authors considered reactive magnetron sputtering as the technique to obtain $\mathrm{TiO}_{2}$ anatase ${ }^{16}$. It has been reported that the preferential growth in anatase is [001] based on Bragg-Brentano XRD analyses ${ }^{17,18}$. Moreover, the ability to control texture and the crystallinity of the $\mathrm{TiO}_{2}$ films allows increased catalytic processes ${ }^{19,20}$. Other authors report that the modification of surface morphology of semiconductor photocatalysts can give rise to a more efficient form for photocatalytic applications ${ }^{21}$.

In addition, photocatalysis with titanium dioxide $\left(\mathrm{TiO}_{2}\right)$ using natural solar radiation is one of the most efficient processes for inactivation of bacteria including E. coli, E. faecalis, Legionella, etc. and some specific fungi (Fusarium sp.) in water ${ }^{22,23}$. Titanium dioxide is still useful as an active material in various applications such as dye-sensitized solar cells $\mathrm{s}^{24}$, fuel cells and optical coatings ${ }^{25}$ water purification ${ }^{26}$. Moreover, $\mathrm{TiO}_{2}$ is used to degrade organic and inorganic pollutants $\mathrm{s}^{27,28}$ to produce antireflection layers on low-emissivity coatings and protective layers ${ }^{29}$.

Titanium dioxide has gained attention owing to its nontoxic, chemical and environmental consistency and interesting optical properties, including its brightness and refractive index in visible region ${ }^{30}$. In addition, $\mathrm{TiO}_{2}$ of high transparency has been deposited in $\mathrm{Ar} / \mathrm{O}_{2}$ plasmas $^{31}$. Recent studies have reported the radiofrequency (RF) sputter deposition of $\mathrm{TiO}_{2}$ using $\mathrm{Ar} / \mathrm{O}_{2}$ plasmas ${ }^{32}$.

\section{MATERIAL AND METHODS}

\section{Preparation of $\mathrm{TiO}_{2}$ film}

The $\mathrm{TiO}_{2}$ thin films were deposited on both glass (dimensions of $75 \times 25 \times 1 \mathrm{~mm}$ ) 33 and polyethylene terephthalate (PET) substrates of $0.05 \times 25 \times 15 \mathrm{~mm}$, in the direct current (DC) magnetron sputtering system schematized in Fig. 1 . The target was titanium of $99.9 \%$ purity and total surface area (TA) of $7854 \mathrm{~mm}^{2}$. The distance between target and substrate was $60 \mathrm{~mm}$.

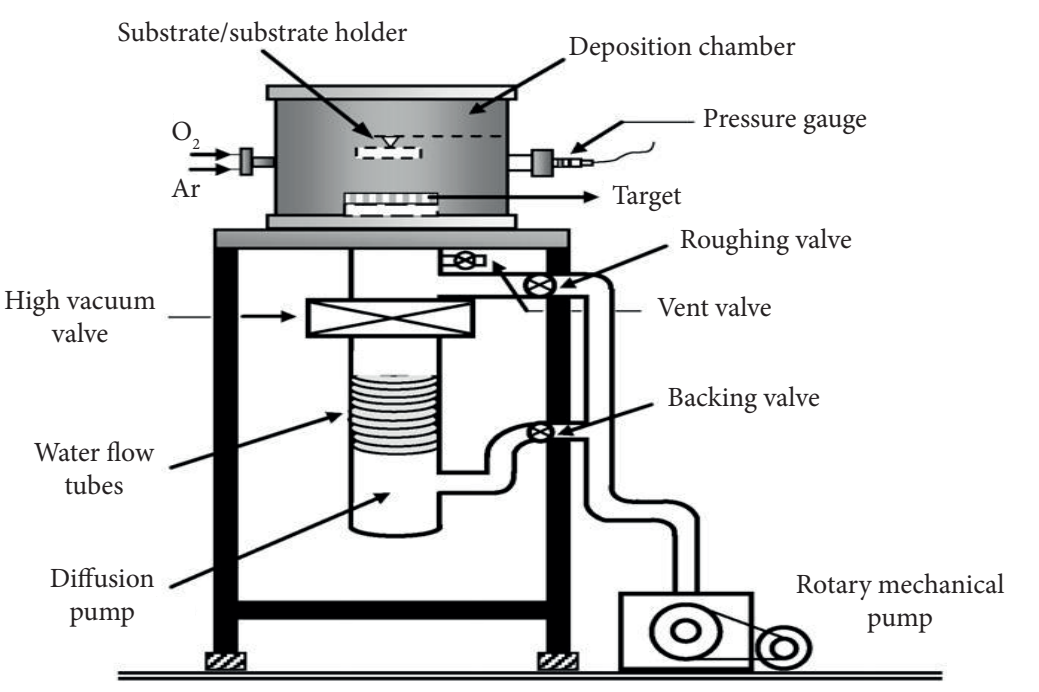

Figure 1: Schematic of the reactive magnetron sputtering film deposition system. 
After the chamber was evacuated to a base pressure lower than $1 \times 10^{-3} \mathrm{~Pa}, 50$ SCCM of pure argon sputtering gas was fed to the chamber, and the discharge begun at a constant current of $0.45 \mathrm{~A}$. After the discharge voltage has stabilized, $99.95 \%$ pure oxygen gas was introduced into the chamber at a constant flow rate of 10 SCCM for a deposition time of 3600 s. Working at a constant argon flow rate and discharge current, the discharge voltage increased from zero up to the threshold (applying three values of oxygen flow rate: 20,25 or $30 \%$ ), indicating that the effective reduction in the area of the metal being sputtered caused the formation of oxide. After that, the target voltage decreased to a stable value corresponding to the compound sputtering mode in which transparent $\mathrm{TiO}_{2}$ films were deposited on the substrates. Low temperature growth of anatase has been reported by a few groups using metallic Ti as a sputtering target ${ }^{34}$.

\section{Photocatalytic activity}

Photocatalytic efficiency of $\mathrm{TiO}_{2}$ is expected to be low under visible light irradiation because UV light is about $<10 \%$ of the overall solar intensity. Thus, increasing the visible light absorption of $\mathrm{TiO}_{2}$ materials may improve the photocatalytic activity by decreasing the energy bandgap or preventing $(\mathrm{e}-\mathrm{h}+\mathrm{h}$ ) pair recombination by electron-hole tapping. In this study, the effects of argon and oxygen in the gas feed for $\mathrm{TiO}_{2}$ growth on the microstructure, light absorption and photocatalytic properties of $\mathrm{TiO}_{2}$ thin films were examined.

According to the literature, a satisfactory catalytic activity is seen when the films have the two phases, with the concomitant increase in the ionic radius of the grains that form the anatase phase. However, in 1995, Linsebigler et al. reported anatase $\mathrm{TiO}_{2} \mathrm{crystals}$ with a gap $\sim 3.2 \mathrm{eV}$ at $\lambda=387 \mathrm{~nm}^{35}$. The same value of bandgap for anatase $\mathrm{TiO}_{2}(3.2 \mathrm{eV})$ was reported in previous studies ${ }^{36,37}$.Most proteins can absorb radiation of $\lambda$ near $280 \mathrm{~nm}$ because of the presence of tyrosine phenylalanine, aromatic compounds and conjugated double bonds in benzene ring. These absorptions are observed in the presence of double bonds $(\pi)$ with transitions $\pi$ to $\pi^{*}$, since $n \AA \pi^{\star}$ transitions are prohibited by the selection rules. It is believed that the degree of unsaturation given by bonds of the $\pi$ type correspond to reduced transmittance compared to $\pi$ type connections. The influence of unsaturation on the formation of biofilms is difficult to predict ${ }^{38}$.

The electrical current and voltage parameters were also varied to seek the best deposition condition and, it can be controlled by the treatment time (deposition). Chemical reactions observed in this process were caused by the photoexcitation mechanism involving the formation of electron-hole pairs and valences. Those reactions can be seen in Fig. 2.

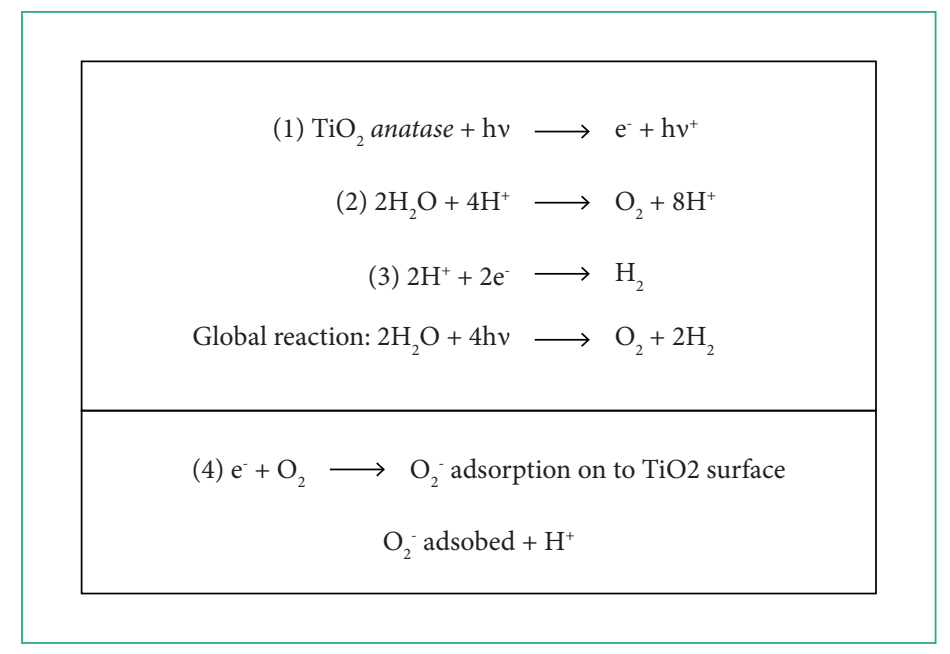

Figure 2: Chemical reactions stimulated by the interaction of a visible light photon with $\mathrm{TiO}_{2}$ deposited on substrates.

There are two types of photochemical reaction proceeding on the $\mathrm{TiO}_{2}$ surface when irradiated with ultraviolet light. One is photoinduced redox reactions of the adsorbed substances through "electron-hole" pairs ${ }^{39}$, and the other is hydrophilic photoinduced conversion of the film itself. Titanium dioxide is one of the most powerful oxidants because of the high oxidizing potential of holes in the valence band formed by photoexcitation ${ }^{40,42}$.

In the absence of a catalytically active substance, the oxidation process of most hydrocarbons proceeds rather slowly. A photocatalyst should decrease the activation energy of a given reaction. A heterogeneous photocatalytic system consists of semiconductor particles (photocatalyst) which are in close contact with a liquid reaction medium. By exposing the catalyst to light, excited states are generated, which are able to initiate subsequent processes, such as redox reactions and molecular changes. Owing to their electronic structure, which is characterized by a filled valence band (VB) and an empty conduction band (CB), metal oxides, such as $\mathrm{TiO}_{2}$, can act as sensitizers for light-induced redox processes. For example, UV light can excite pairs of electrons and holes; an electron $\left(\mathrm{e}^{-}{ }_{\mathrm{CB}}\right)$ is promoted to the conduction band while a positive hole $\left(\mathrm{h}+{ }_{\mathrm{vB}}\right)$ is generated in the valence band. The photo-generated electrons then react with molecular 
oxygen $\left(\mathrm{O}_{2}\right)$ to produce super-oxide radical anions $\left(\mathrm{O}_{2}^{-}\right)$, and the photo-generated holes react with water to produce hydroxyl $\left(\mathrm{OH}^{-}\right)$ radicals. These two types of reactive radicals can work together to decompose organic compounds.

\section{Characterization and conditions}

A Shimadzu UV-310PC scanning spectrophotometer was used to measure the transmittance spectrum of $\mathrm{TiO}_{2}$ films as a function in the wavelength range from 200 to $900 \mathrm{~nm}$. This procedure is highly reproducible, and no error-bar was generated. Table 1 shows the parameters adopted for these series of depositions. The temperature determined by the plasma kinetics ranged from 40 and $45{ }^{\circ} \mathrm{C}$.

Table 1: Initial conditions for TiO2 deposition, described by the code \#A (Ar and O proportion).

\begin{tabular}{|c|c|c|c|c|c|c|}
\hline Experimental parameters & $\begin{array}{c}\# A 1 \\
\text { Ar }=20 \% \\
(50 \text { SCCM) } \\
\text { O2 = } 25 \% \\
\text { (10 SCCM) }\end{array}$ & $\begin{array}{c}\text { \#A2 } \\
\text { Ar }=20 \% \\
(50 \text { SCCM) } \\
\text { O2 = } 25 \% \\
(10 \text { SCCM) }\end{array}$ & $\begin{array}{c}\# A 3 \\
\text { Ar }=20 \% \\
(50 \text { SCCM) } \\
\text { O2 = } 30 \% \\
(10 \text { SCCM) }\end{array}$ & $\begin{array}{c}\text { \#A4 } \\
\text { Ar }=35 \% \\
(50 \text { SCCM) } \\
\text { O2 = 20\% } \\
\text { (10 SCCM) }\end{array}$ & $\begin{array}{c}\text { \#A5 } \\
\text { Ar }=35 \% \\
(50 \text { SCCM) } \\
\text { O2 = } 20 \% \\
(10 \text { SCCM) }\end{array}$ & $\begin{array}{c}\text { \#A6 } \\
\text { Ar }=45 \% \\
(50 \text { SCCM) } \\
\text { O2 = } 20 \% \\
\text { (10 SCCM) }\end{array}$ \\
\hline Electric current $(\mathrm{A})$ & 0.45 & 0.45 & 0.45 & 0.2 & 0.2 & 0.2 \\
\hline Voltage (V) & 519 & 517 & 507 & 437 & 437 & 416 \\
\hline RF power (W) & 233 & 232 & 228 & 87 & 87 & 83 \\
\hline Deposition time (s) & 3600 & 3600 & 3600 & 3600 & 3600 & 3600 \\
\hline Background pressure (mbar) & $6.3 \times 10^{-3}$ & $6.4 \times 10^{-3}$ & $5.7 \times 10^{-3}$ & $9.2 \times 10^{-3}$ & $9.2 \times 10^{-3}$ & $1.26 \times 10^{-3}$ \\
\hline
\end{tabular}

In addition, Table 2 shows the different sample positions on the electrode for the deposition of $\mathrm{TiO}_{2}$ films.

Table 2: Sample positions on the electrode for the second series of experiments identified by \#B1 to \#B6.

$\begin{array}{cc}\text { Code } & \text { Placement/assignment } \\ \text { \#B1 } & \text { Glass in the center of the electrode holder associated with the condition \#A5 } \\ \text { \#B2 } & \text { Glass in the electrode holder edge associated with the condition \#A5 } \\ \text { \#B3 } & \text { Glass in the center of the electrode holder associated with the condition \#A6 } \\ \text { \#B5 } & \text { Glass in the electrode holder edge associated with the condition \#A6 } \\ \text { \#B6 } & \text { PET in the electrode holder edge associated with the condition \#A5 }\end{array}$

\section{RESULTS}

\section{Crystallographic directions, composition of $\mathrm{TiO}_{2}$ films}

The $\mathrm{TiO}_{2}$ films deposited under these conditions were studied using X-ray diffraction (XRD) and X-ray photoelectron spectroscopy (XPS). For some applications such as transparent conductors, the anatase phase with its larger crystallite size is preferable to obtain electrons mobilities. The average crystallite sizes for the $\mathrm{TiO}_{2}$ films can be calculated from the broadening of the diffraction peak using Scherrer's formula, $\mathrm{D}=0.9 \mathrm{k} / \mathrm{B} \cosh$, where $\mathrm{k}$ is the wavelength of $\mathrm{Cu} \mathrm{K}_{\alpha}$ radiation, $\mathrm{B}$ is the full width at half maximum (FWHM) of XRD peaks and $\mathrm{h}$ the Bragg diffraction angle of the line ${ }^{43}$. At $\mathrm{T}_{\text {substrate }} \geqslant 200{ }^{\circ} \mathrm{C}$, the films tend to have random crystallite orientation and exhibit $\left(\begin{array}{lll}0 & 0\end{array}\right)$ and $\left(\begin{array}{lll}2 & 0 & 0\end{array}\right)$ reflections of the anatase phase, indicating that the growth temperature has a great impact on the structural properties of the prepared $\mathrm{TiO}_{2}$ films ${ }^{44}$.

The O1s XPS spectrum of $\mathrm{TiO}_{2}$ films deposited in Ar-O plasmas was studied. The presence of an asymmetric component at the higher binding energy (BE) side with respect to the main peak (OI) indicates the existence of different chemical states of oxygen. The peak is deconvoluted into two components: the first at lower BE $(530.64 \mathrm{eV})$ can be ascribed to the O1s core peak of O2- bound to Ti4+ in $\mathrm{TiO}_{2}{ }^{45}$, whereas the higher BE component located at $531.82 \mathrm{eV}$, may arise from the contribution of oxygen to Ti-OH bonds ${ }^{46}$. The other component (OII) at the higher $\mathrm{BE}$ of $532.62 \mathrm{eV}$ is associated with adsorbed molecular bonds such as $\mathrm{C}=\mathrm{O}, \mathrm{O}-\mathrm{C}-\mathrm{O}$ or $\mathrm{O}=\mathrm{C}-\mathrm{O}{ }^{47}$. Carbon probably was ejected from PET by sputtering and etching reactions, linking with oxygen introduced in vacuum chamber.

\section{Optical transmittance in the UV-visible region}

Titanium oxide films are transparent in the visible region and their transparency shows a sharp decrease in the UV region. For the initial studied samples, Fig. 3 shows the transmittance curves $T(\lambda)$ as a function of wavelength for different proportions of argon and 
oxygen gases, while Fig. 4 shows the results for different positions of the substrates on the upper electrode. The spectra were acquired immediately after removal of the samples from the reactor (also, immediately after deposition).Ultraviolet photons excite electrons from the valence band ( $\mathrm{vb}$ ) to conduction band (cb), leading to two types of charge carriers, electrons (ecb-) and holes (hvb+). These carriers are responsible for the activation of chemical reactions ${ }^{48,49}$.

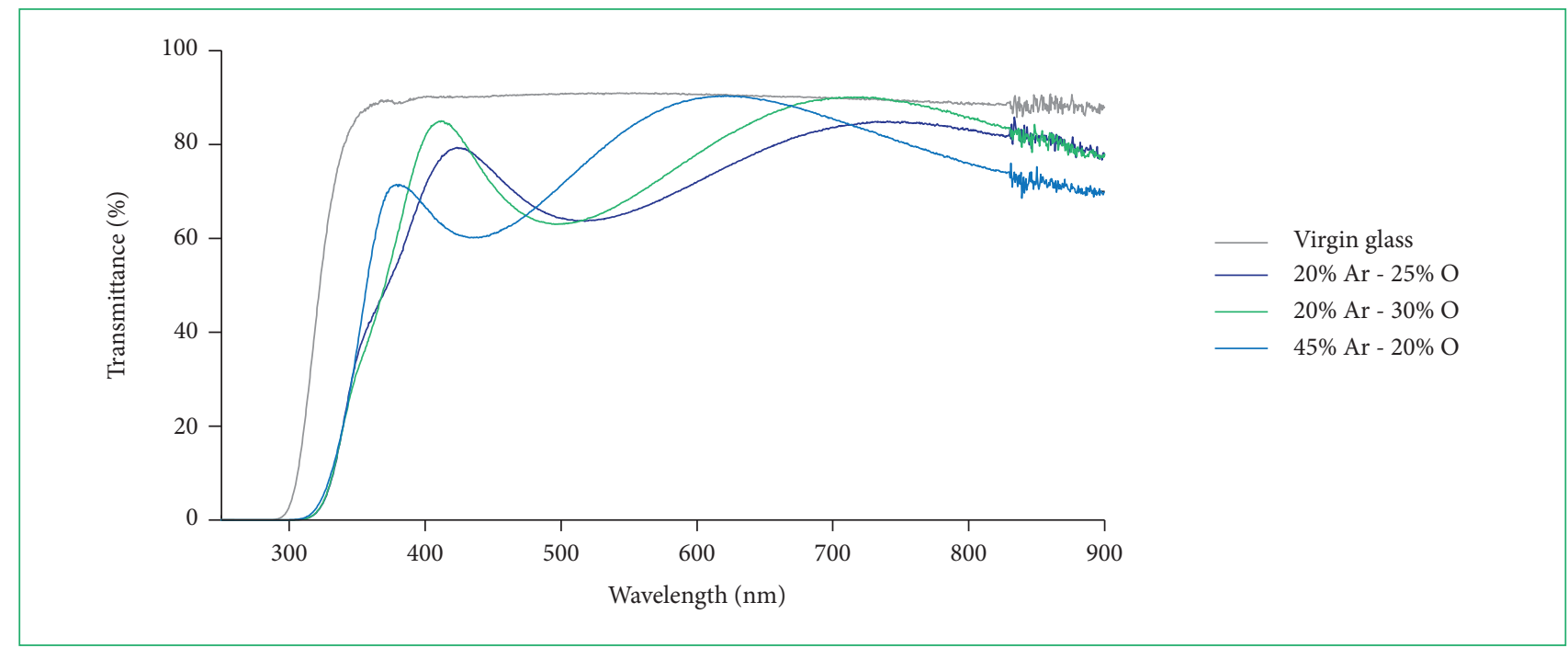

Figure 3: Optical transmittance as a function of wavelength $(\lambda)$ in the visible region, measured on the $\mathrm{TiO}_{2}$ deposited on glass by $\mathrm{RF}$ magnetron sputtering. The flow rates of argon and oxygen were 10 and 50 SCCM, respectively, for a deposition time of $3600 \mathrm{~s}$.

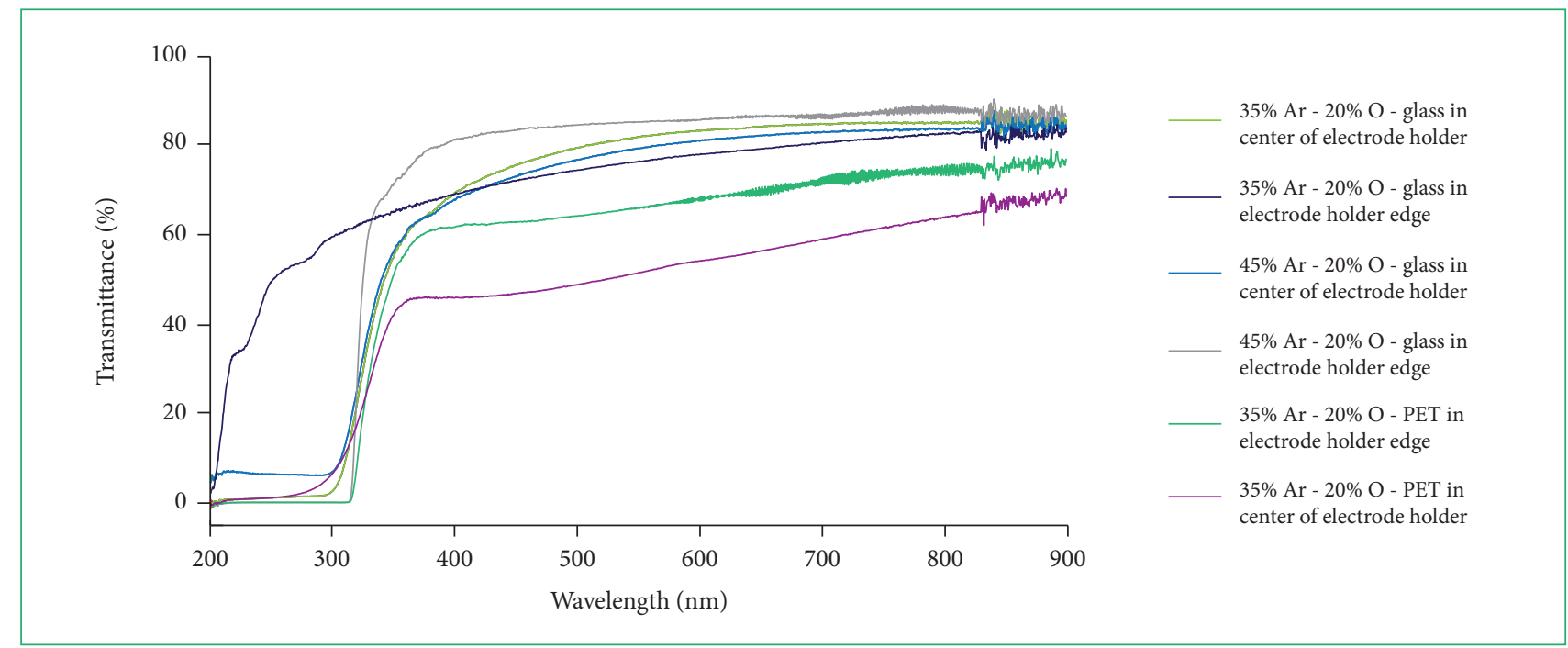

Figure 4: Optical transmittance as a function of wavelength in the visible of $\mathrm{TiO}_{2}$ deposited onto glass substrates by $\mathrm{RF}$ magnetron sputtering. The flow rates of argon and oxygen were 10 and 50 SCCM, respectively, for a deposition time of $3600 \mathrm{~s}$.

A sharp decrease in the $\mathrm{T}(\lambda)$ curves in the visible region was seen for all gas proportions shown in Fig. 3 and, except under condition B3, also seen in Fig. 4. This implies that a polymer packing with this film in most of conditions, when exposed to ambient light may have on its surface an antimicrobial activity stimulated by photocatalysis caused by UV light through films, since absorption occurs in the visible region, including the blue ultraviolet radiation. Harmful bacteria may be destroyed when exposed to radiation of $\lambda$ between 190 and $250 \mathrm{~nm}$. The bactericide action of $\mathrm{TiO}_{2}$ arises from the existence of reactive groups, such as hydroxyl, on its surface. Reactive species, such as $-\mathrm{OH}$ and $\mathrm{O}^{2-}$, decompose organic compounds. This mechanism is responsible for the antibacterial action of irradiated $\mathrm{TiO}_{2}$ surfaces ${ }^{50}$. Ultraviolet irradiation of $\mathrm{TiO}_{2}$ promotes electrons (e-) from the valence band to the conduction band, which leaves positive charge carrier holes (hp) in the valence band. The e- and hp charges migrate in random directions to the bulk or the surface. Those elementary charges that reach the surface of the catalyst can react with electron-donor and electron-acceptor species present at the semiconductor/electrolyte interface ${ }^{51}$.Moreover, the high absorption below $200 \mathrm{~nm}$ is associated with crystal-field splitting. It is known that $\mathrm{Ti}$ has octahedral coordination in anatase $\mathrm{TiO}_{2}$ causing a crystal-field splitting of the d-orbitals of titanium into two subbands: the 
eg and the $\mathrm{t} 2 \mathrm{~g}$ orbitals ${ }^{52}$; the eg orbitals ( $\mathrm{dz2}$ and $\left.\mathrm{dx} 2-\mathrm{y} 2\right)$ which point directly toward the oxygen ligands and form r-type orbitals; the $\mathrm{t} 2 \mathrm{~g}$ orbitals (dxy, dyz and dxz) point between the oxygen neighbors and form p-orbitals. The repulsive force between the dxy, dyz, $d x z$ and oxygen ligands is weaker leading to a decreased energy for those orbitals. The $\operatorname{Ti}(3 \mathrm{~d} 4 \mathrm{~s} 4 \mathrm{p})$ orbitals are then linearly combined with the $\mathrm{O}(2 \mathrm{~s} 2 \mathrm{p})$ orbitals to form the molecular orbitals.Previous studies revealed that the upper $\mathrm{t}_{2 \mathrm{~g}}^{*}$ and $\mathrm{e}_{\mathrm{g}}^{*}$ are mainly of Ti3d character and form the conduction band, and the lower $\mathrm{t}_{2 \mathrm{~g}}$ and $\mathrm{e}_{\mathrm{g}}$ are mainly of $\mathrm{O} 2 \mathrm{p}$ character and form the valence band ${ }^{53,54}$.

\section{DISCUSSION}

In recent decades, $\mathrm{TiO}_{2}$ semiconductors have attracted great interest due to their low cost and low toxicity, together with their high transparency, high refractive index, and good chemical stability. Nowadays, $\mathrm{TiO}_{2}$ thin films are used for a variety of applications, ranging from selective absorbing coatings to photovoltaic solar cells, gas sensors and photocatalysis. The literature reports the use of $\mathrm{TiO}_{2}$ films in advanced oxidative processes (POA), mainly in heterogeneous photocatalysis ${ }^{55}$. The use of thin films of $\mathrm{TiO}_{2}$ in heterogeneous photocatalysis is possible because of its semiconducting characteristics, since it is active under irradiations for $300 \mathrm{~nm}<\lambda<390 \mathrm{~nm}$ and remains stable after many catalytic cycles ${ }^{56}$, owing to its large bandgap (3.2 eV) ${ }^{57-59}$.Semiconductor photocatalysis is one of the most promising processes for purification of water ${ }^{60,61}$. Some studies point out that anatase $\mathrm{TiO}_{2}$ has $\mathrm{more}^{\mathrm{a}}$ efficient photocatalytic properties ${ }^{62}$. Moreover, some studies report that the addition of $\mathrm{H}_{2} \mathrm{O}_{2}$ as a photocatalytic activity accelerator has also been evaluated under natural sunlight. A weight relation of $1: 2$ of $\mathrm{TiO}_{2}$ to $\mathrm{H}_{2} \mathrm{O}_{2}$ was tested ${ }^{63}$, using the $\mathrm{TiO}_{2}$ concentration that gave the fastest inactivation, i.e. $35 \mathrm{mg} \mathrm{L}^{-1}$ of $\mathrm{TiO}_{2}$. On the other hand, samples with only $\mathrm{TiO}_{2}$ were more efficient for the inactivation of Cryptosporidium parvum in water under simulated and natural solar radiation. A complete account of the mechanism of bacterial in activation has been reported in some recent reviews ${ }^{64}$. The preparation of $\mathrm{TiO}_{2}$ thin films by sputtering has prominent advantages such as clean process (without intermediate chemical products), high reproducibility and easy scale-up to produce uniform films on large area substrates. Different sputtering processes have been used for $\mathrm{TiO}_{2}$ deposition, in $\mathrm{RF}$ or $\mathrm{DC}_{\text {modes }}{ }^{65}$.In the case of $\mathrm{TiO}_{2} /$ solar radiation, the inhibition of the process may be caused by the effect of clogging the catalyst surface by organic molecules or microorganisms already present in this type of water. Therefore, competition occurs for the holes generated on the surface of the $\mathrm{TiO}_{2}$. When $\mathrm{H}_{2} \mathrm{O}_{2}$ is added to $\mathrm{TiO}_{2}$, an enhancement occurs because of the already described process of inhibition of electron/hole recombination is reduced and therefore generates more $\mathrm{HO} \cdot{ }^{66}$. When a semiconductor is excited with sunlight, absorption of photons with energy higher than the band gap leads to the creation of electron-hole pairs. These photoexcited charge carriers react with the adsorbed oxygen molecules and water molecules leading to the formation of superoxide radicals $(\bullet \mathrm{O} 2-)$ and hydroxyl $(\bullet \mathrm{OH})$ radicals, respectively. These reactive oxygen species interact with the adsorbed toxic pollutants resulting in their degradation ${ }^{67-69}$. Thus, the authors of this work strongly recommend growing films under the conditions given by this work for photocatalysis, and the optical spectra confirm the suggested applications, since they presented high transmittance in the visible region, up to $350 \mathrm{~nm}$, and high absorption near to and below $300 \mathrm{~nm}$, which stimulates photocatalytic activity.About degradative processes on substrates: It is characteristic for UV degradative processes to occur under oxygen starvation and diminished UV beam penetration across the material thickness. Oxygen diffusion-limited reaction is caused when the oxygen from the atmosphere is consumed by rapid reaction near the illuminated surface before it can diffuse into the interior to react there ${ }^{70}$. It is quite common in photooxidation of polymers. Oxygen starvation depends on the diffusion coefficient for oxygen in a particular polymer. It is, for example, two orders of magnitude smaller for PET than for polyethylene ${ }^{70}$. The PET samples used in this work did not present any signal of degradation, due to UV radiation generated by the plasma deposition. Anyway, it is suggested to study the mechanisms of photodegradation of PET under UV for future studies, whose conditions can be found in Fechine et al. ${ }^{71,72}$.

\section{CONCLUSION}

Radiofrequency magnetron sputtering is an excellent technique to grow anatase $\mathrm{TiO}_{2}$ films for photocatalysis reactions. The material produced is suitable for some important applications such as water treatment, pollutant treatment, self-cleaning surfaces, so on. The spectra reveal good deposition conditions for all argon/oxygen proportions, since the curves were dislocated in relation to those of glass substrates, yielding high transmittance in the visible, up to $350 \mathrm{~nm}$, and high absorption near to and below $300 \mathrm{~nm}$, which stimulates photocatalytic activity. In relation to the spectrum as a function of the sample position on the electrodes, only condition \#B2 (glass in the electrode edge) did not result in high absorption in the visible region. At the electrode edge, there is no linear electric field, and the film does not grow. The best condition (\#A5, \#B1) produced high transmittance for longer wavelengths in the visible (up to $350 \mathrm{~nm}$ ), high absorption for lower wavelengths in the visible to UV-visible, with low surface roughness ( 5 $\mathrm{nm}$ ). 


\section{FUNDING}

Conselho Nacional de Desenvolvimento Científico e Tecnológico [https://.doi.org/10.13039/501100003593]

Fundação de Amparo à Pesquisa do Estado de São Paulo [https://doi.org/10.13039/501100001807]

\#Project 2017/15853-0

\section{REFERENCES}

1. Abdin Z, Alim MA, Saidur R, Islam MR, Rashmi W, Mekhilef S, et al. Solar energy harvesting with the application of nanotechnology. Renew Sust Energ Rev. 2013;26:837-52. https://doi.org/10.1016/j.rser.2013.06.023

2. Maçaira J, Andrade L, Mendes A. Review on nanostructured photoelectrodes for next generation dye-sensitized solar cells. Renew Sust Energ Rev. 2013;27:334-49. https://doi.org/10.1016/j.rser.2013.07.011

3. Henkel B, Neubert T, Zabel S, Lamprecht C, Selhuber-Unkel C, Rätzke K, et al. Photocatalytic properties of titania thin films prepared by sputtering versus evaporation and aging of induced oxygen vacancy defects. Appl Catal B Environ. 2016;180:362-71. https://doi.org/10.1016/i. apcatb.2015.06.041

4. Ananth A, Gandhi MS, Mok YS. A dielectric barrier discharge (DBD) plasma reactor: an efficient tool to prepare novel RuO2 nanorods. J Phys D: Appl Phys. 2013;46(15):155202. https://doi.org/10.1088/0022-3727/46/15/155202

5. Wang D, Yang Q, Guo Y, Liu X, Shi J, Zhang J. One step growth of TiO2 crystal trees by atmospheric pressure plasma jet. Mater Lett. 2011;65(15-16):2526-9. https://doi.org/10.1016/j.matlet.2011.05.054

6. Zille A, Fernandes MM, Francesko A, Tzanov T, Fernandes M, Oliveira FR, et al. Size and aging effects on antimicrobial efficiency of silver nanoparticles coated on polyamide fabrics activated by atmospheric DBD plasma. ACS Appl Mater Interfaces. 2015;7(25):13731-44.https:// doi.org/10.1021/acsami.5b04340

7. Ostrikov KK, Seo DH, Mehdipour H, Cheng Q, Kumar S. Plasma effects in semiconducting nanowire growth. Nanoscale. 2012;4(5):1497-1508 https://doi.org/10.1039/C1NR10658A

8. Attri P, Arora B, Choi EH. Retraction: Utility of plasma: a new road from physics to chemistry. RSC Adv. 2013;3:12540-67. Erratum in: RSC Adv 2017;7:15735. https://doi.org/10.1039/C7RA90034A

9. Li ML, Huang GS, Wang DX, Zhang J, Shi JJ, Mei YF. Atmospheric growth and strong visible luminescence of anatase titanium oxide films with various orientations. J Mater Chem A. 2014;2(19):6708-13. https://doi.org/10.1039/C4TA00730A

10. Mardare D, Tasca M, Delibas M, Rusu GI. On the structural properties and optical transmittance of TiO2 r.f. sputtered thin films. Appl Surf Sci. 2000;156(1-4):200-6. https://doi.org/10.1016/S0169-4332(99)00508-5

11. Thongsuriwong K, Amornpitoksuk P, Suwanboon S. Structure, morphology, photocatalytic and antibacterial activities of ZnO thin films prepared by sol-gel dip-coating method. Adv Powder Technol. 2013;24(1):275-80. https://doi.org/10.1016/j.apt.2012.07.002

12. Ken-Ichi O, Yasunori Y, Hiroki T, Masashi T, Akira I. Heterogeneous photocatalytic decomposition of phenol over TiO2 powder. Bull Chem Soc Jpn. 1985;58(7):2015-22. https://doi.org/10.1246/bcsj.58.2015

13. Chen Q, Liu Q, Hubert J, Huang W, Baert K, Wallaert G, et al. Deposition of photocatalytic anatase titanium dioxide films by atmospheric dielectric barrier discharge. Surf Coat Technol. 2017;310:173-9. https://doi.org/10.1016/j.surfcoat.2016.12.077

14. Marschall R. Semiconductor composites: Strategies for enhancing charge carrier separation to improve photocatalytic activity. Adv Funct Mater. 2014;24(17):2421-40. https://doi.org/10.1002/adfm.201303214

15. Liu L, Zhao H, Andino JM, Li Y. Photocatalytic CO2 reduction with $\mathrm{H} 2 \mathrm{O}$ on TiO2 nanocrystals: comparison of anatase, rutile, and brookite polymorphs and exploration of surface chemistry. ACS Catal. 2012;2(8):1817-28. https://doi.org/10.1021/cs300273q

16. Wang Z, Zeng W, Gu L, Saito M, Tsukimoto S, Ikuhara Y. Atomic-scale structure and electronic property of the LaAlO3/TiO2 interface. J Appl Phys. 2010;108(11):113701. https://doi.org/10.1063/1.3516496

17. Xu H, Feng X, Luan C, Ma J. Preparation and characterization of single crystalline anatase TiO2 epitaxial films on LaAIO3(001) substrates by metal organic chemical vapor deposition. Scr Mater. 2016;124:76-80. https://doi.org/10.1016/j.scriptamat.2016.06.040

18. Krupski K, Sanchez AM, Krupski A, McConville CF. Optimisation of anatase TiO2 thin film growth on LaAIO3(0 01$)$ using pulsed laser deposition. Appl Surf Sci. 2016;388(B):684-90. https://doi.org/10.1016/j.apsusc.2016.02.214

19. Luttrell T, Halpegamage S, Tao J, Kramer A, Sutter E, Batzill M. Why is anatase a better photocatalyst than rutile? - Model studies on epitaxia TiO2 films. Sci Rep. 2014:4:4043. https://doi.org/10.1038/srep04043

20. Wu HB, Chen JS, Hng HH, Lou XWD. Nanostructured metal oxide-based materials as advanced anodes for lithium-ion batteries. Nanoscale. 2012;4(8):2526-42. https://doi.org/10.1039/c2nr11966h

21. Gaya UI. Heterogeneous photocatalysis using inorganic semiconductor solids. Dordrecht: Springer; 2014. https://doi.org/10.1007/978-94-007$7775-0$ 
22. Polo-López MI, Castro-Alférez M, Oller I, Fernández-lbáñez P. Assessment of solar photo-Fenton, photocatalysis, and H2O2 for removal of phytopathogen fungi spores in synthetic and real effluents of urban wastewater. Chem Eng J. 2014;257:122-30. https://doi.org/10.1016/j. cej.2014.07.016

23. Rodríguez-Chueca J, Polo-López MI, Mosteo R, Ormad MP, Fernández-lbáñez P. Disinfection of real and simulated urban wastewater effluents using a mild solar photo-Fenton. Appl Catal B Environ. 2014;150-151:619-29. https://doi.org/10.1016/j.apcatb.2013.12.027

24. Chamanzadeh Z, Noormohammadi M, Zahedifar M. Enhanced photovoltaic performance of dye sensitized solar cell using TiO2 and ZnO nanoparticles on top of free standing TiO2 nanotube arrays. Mater Sci Semicond Process. 2017;61:107-13. https://doi.org/10.1016/j. mssp.2017.01.006

25. Mazur M, Wojcieszak D, Kaczmarek D, Domaradzki J, Song S, Gibson D, et al. Functional photocatalytically active and scratch resistant antireflective coating based on TiO2 and SiO2. Appl Surf Sci. 2016;380:165-71. https://doi.org/10.1016/j.apsusc.2016.01.226

26. Arcadipane E, Sanz R, Miritello M, Impellizzeri G, Grimaldi MG, Privitera V, et al. TiO2 nanowires on Ti thin film for water purification. Mater Sci Semicond Process. 2016;42(1):24-7. https://doi.org/10.1016/j.mssp.2015.07.055

27. Natarajan S, Bhuvaneshwari M, Lakshmi DS, Mrudula P, Chandrasekaran N, Mukherjee A. Antibacterial and antifouling activities of chitosan/ TiO2/Ag NPs nanocomposite films against packaged drinking water bacterial isolates. Environ Sci Pollut Res Int. 2016;23(19):19529-40. https:// doi.org/10.1007/s11356-016-7102-6

28. Cozmuta AM, Peter A, Cozmuta LM, Nicula C, Crisan L, Baia L, et al. Active packaging system based on Ag/TiO2 nanocomposite used for extending the shelf life of bread. Chemical and microbiological investigations. Packag Technol Sci. 2015;28(4):271-84. https://doi.org/10.1002/ pts. 2103

29. Mohamad SH, Idris MI, Abdullah HZ, Ismail AF. Short review of ultrafiltration of polymer membrane as a self-cleaning and antifouling in the wastewater system. Adv Mat Res. 2013;795:318-23. https://doi.org/10.4028/www.scientific.net/AMR.795.318

30. Xu Y, Zhang M, Zhang M, Lv J, Jiang X, He G, et al. Controllable hydrothermal synthesis, optical and photocatalytic properties of TiO2 nanostructures. Appl Surf Sci. 2014;315:299-306. https://doi.org/10.1016/j.apsusc.2014.07.110

31. Tao J, Pan H, Wong LM, Wong TI, Chai JW, Pan J, et al. Mechanism of insulator-to-metal transition in heavily Nb doped anatase TiO2. Mater Res Express. 2014;1(1):015911. https://doi.org/10.1088/2053-1591/1/1/015911

32. Safeen K, Micheli V, Bartali R, Gottardi G, Safeen A, Ullah H, et al. Synthesis of conductive and transparent Nb-doped TiO2 films: Role of the target material and sputtering gas composition. Mater Sci Semicond Process. 2017;66:74-80. https://doi.org/10.1016/j.mssp.2017.04.012

33. Molamohammadi M, Arman A, Achour A, Astinchap B, Ahmadpourian A, Boochani A, et al. Microstructure and optical properties of cobaltcarbon nanocomposites prepared by RF-sputtering. J Mater Sci: Mater Electron. 2015;26(8):5964-69. https://doi.org/10.1007/s10854-0153170-5

34. Karuppasamy A, Subrahmanyam A. Studies on the room temperature growth of nanoanatase phase TiO2 thin films by pulsed dc magnetron with oxygen as sputter gas. J Appl Phys. 2007;101(6):064318. https://doi.org/10.1063/1.2714770

35. Linsebigler AL, Lu G, Yates JT. Photocatalysis on TiO2 surfaces: principles, mechanisms, and selected results. Chem Rev. 1995;95(3):735-58. https://doi.org/10.1021/cr00035a013

36. Castro MV, Rebouta L, Alpuim P, Cerqueira MF, Benelmekki M, Garcia CB, et al. Optimisation of surface treatments of TiO2:Nb transparent conductive coatings by a post-hot-wire annealing in a reducing H2 atmosphere. Thin Solid Films. 2014;550:404-12. https://doi.org/10.1016/j. tsf.2013.11.044

37. Nair PB, Justinvictor VB, Daniel GP, Joy K, Raju KCJ, Kumar DD, et al. Optical parameters induced by phase transformation in RF magnetron sputtered TiO2 nanostructured thin films. Prog Nat Sci. 2014;24(3):218-25. https://doi.org/10.1016/j.pnsc.2014.05.010

38. Sant'Ana PL. Polymers treated by plasma for optical devices and food packaging: Giving a technological ends for commercial and recycled plastics. Australia: Scholars' Press; 2018.

39. Kaneko M, Okura I. Photocatalysis: Science and Technology (Biological and Medical Physics, Biomedical Engineering). Berlin: Springer; 2002.

40. Gaya UI, Abdullah AH. Heterogeneous photocatalytic degradation of organic contaminants over titanium dioxide: A review of fundamentals, progress and problems. J Photochem Photobiol C: Photochem. Rev. 2008;9(1):1-12. https://doi.org/10.1016/j.jphotochemrev.2007.12.003

41. Hoffmann MR, Martin ST, Choi W, Bahnemann DW. Environmental Applications of Semiconductor Photocatalysis. Chem Rev. 1995;95(1):69-96. https://doi.org/10.1021/cr00033a004

42. Morrison SR. Electrochemistry at semiconductor and oxidized metal electrodes. New York: Plenum Press; 1980.

43. Cullity BD. Elements of X-ray diffraction. Michigan: Addison-Wesley Publishing Company; 1978.

44. Singh P, Kaur D. Room temperature growth of nanocrystalline anatase TiO2 thin films by dc magnetron sputtering. Physica B Condens Matter. 2010;405(1):1258-66. https://doi.org/10.1016/j.physb.2009.11.061

45. Moulder JF, Stickle WF, Sobol PE, Bomben KD. Handbook of X-ray photoelectron spectroscopy: a reference book of standard spectra for identification and interpretation of Xps data. Eden Prairie: Physical Electronics; 1995

46. Beamson G, Briggs D. High resolution monochromated X-ray photoelectron spectroscopy of organic polymers: A comparison between solid state data for organic polymers and gas phase data for small molecules. Mol Phys. 1992;76(4):919-36. https://doi.org/10.1080/00268979200101761 
47. Luciu I, Bartali R, Laidani N. Influence of hydrogen addition to an Ar plasma on the structural properties of TiO2-x thin films deposited by RF sputtering. J Phys D: Appl Phys. 2012;45(34):345302. https://doi.org/10.1088/0022-3727/45/34/3453

48. Yang, L, Yu LE, Ray MB. Photocatalytic oxidation of paracetamol: dominant reactants, intermediates, and reaction mechanisms. Environ. Sci. Technol. 2009;43(2):460-65 https://doi.org/10.1021/es8020099

49. Banerjee S, Dionysiou DD, Pillai SC. Self-cleaning applications of TiO2 by photo-induced hydrophilicity and photocatalysis. Appl Catal B Environ. 2015;176-177:396-428. https://doi.org/10.1016/j.apcatb.2015.03.058

50. Soethe VL, Delatorre RG, Ramos EM, Parucker ML. TiO2 thin films for biofouling applications. Mat Res. 2017;20(Suppl 2):426-31. https://doi. org/10.1590/1980-5373-mr-2016-1116

51. Fujishima A, Zhang X, Tryk DA. TiO2 photocatalysis and related surface phenomena. Surf Sci Rep. 2008;63(12):515-82. https://doi. org/10.1016/j.surfrep.2008.10.001

52. Diebold U. The surface science of titanium dioxide. Surf Sci Rep. 2003;48(5-8):53-229. https://doi.org/10.1016/S0167-5729(02)00100-0

53. Yu J, Zhao X, Zhao Q. Effect of surface structure on photocatalytic activity of TiO2 thin films prepared by sol-gel method. Thin Solid Films. 2000;379(1-2):7-14. https://doi.org/10.1016/S0040-6090(00)01542-X

54. Cardona M, Harbeke G. Optical properties and band structure of wurtzite-type crystals and rutile. Phys Rev. 1965;137(5A):A1467. https:// doi.org/10.1103/PhysRev.137.A1467

55. Guz R, Moura C, Cunha MAA, Rodrigues MB. Factorial design application in photocatalytic wastewater degradation from TNT industry-red water. Environ Sci Pollut Res. 2017;24(7):6055-60. https://doi.org/10.1007/s11356-016-6460-4

56. Shyniya CR, Bhabu KA, Rajasekaran TR. Enhanced electrochemical behavior of novel acceptor doped titanium dioxide catalysts for photocatalytic applications. J Mater Sci: Mater Electron. 2017;28(9):6959-70. https://doi.org/10.1007/s10854-017-6396-6

57. Ge S, Xu H, Wang W, Cao R, Wu Y, Xu W, et al. The improvement of open circuit voltage by the sputtered TiO2 layer for efficient perovskite solar cell. Vacuum. 2016;128:91-8. https://doi.org/10.1016/j.vacuum.2016.03.013

58. Schneider J, Matsuoka M, Takeuchi M, Zhang J, Horiuchi Y, Anpo M, et al. Understanding TiO2 photocatalysis: mechanisms and materials Chem Rev. 2014;114(19):9919-86. https://doi.org/10.1021/cr5001892

59. Bai J, Zhou B. Titanium dioxide nanomaterials for sensor applications. Chem Rev. 2014;114(19):10131-76. https://doi.org/10.1021/cr400625

60. Mills A, Davies RH, Worsley D. Water purification by semiconductor photocatalysis. Chem Soc Rev. 1993;22:417-25. https://doi.org/10.1039/ CS9932200417

61. Singh J, Sahu K, Pandey A, Kumar M, Ghosh T, Satpati B, et al. Atom beam sputtered Ag-TiO2 plasmonic nanocomposite thin films for photocatalytic applications. Appl Surf Sci. 2017;411:347-54. https://doi.org/10.1016/j.apsusc.2017.03.152

62. Ogawa H, Higuchi T, Nakamura A, Tokita S, Miyazaki D, Hattori T, et al. Growth of TiO2 thin film by reactive RF magnetron sputtering using oxygen radical. J Alloys Compd. 2008;499(1-2):375-8. https://doi.org/10.1016/j.jallcom.2006.02.103

63. Abeledo-Lameiro MJ, Reboredo-Fernández A, Polo-López MI, Fernández-lbáñez P, Ares-Mazás E, Gómez-Couso H. Photocatalytic inactivation of the waterborne protozoan parasite Cryptosporidium parvum using TiO2/H2O2 under simulated and natural solar conditions Catal Today. 2017;280(1):132-8. https://doi.org/10.1016/j.cattod.2016.05.046

64. Podporska-Carroll J, Panaitescu E, Quilty B, Wang L, Menon L, Pillai SC. Antimicrobial properties of highly efficient photocatalytic TiO2 nanotubes. Appl Catal B Environ. 2015;176-177;70-5. https://doi.org/10.1016/j.apcatb.2015.03.029

65. Guillén C, Montero J, Herrero J. Anatase and rutile TiO2 thin films prepared by reactive DC sputtering at high deposition rates on glass and flexible polyimide substrates. J Mater Sci. 2014;49(14):5035-42. https://doi.org/10.1007/s10853-014-8209-0

66. Aguas Y, Hincapie M, Fernández-lbáñez P, Polo-López MI. Solar photocatalytic disinfection of agricultural pathogenic fungi (Curvularia sp.) in real urban wastewater. Sci Total Environ. 2017;607-608:1213-24. https://doi.org/10.1016/j.scitotenv.2017.07.085

67. Singh J, Satpati B, Mohapatra S. Structural, optical and plasmonic properties of Ag-TiO2 hybrid plasmonic nanostructures with enhanced photocatalytic activity. Plasmonics. 2017;12(3):877-88. https://doi.org/10.1007/s11468-016-0339-6

68. Wang L, Liu S, Wang Z, Zhou Y, Qin Y, Wang ZL. Piezotronic effect enhanced photocatalysis in strained anisotropic ZnO/TiO2 nanoplatelets via thermal stress. ACS Nano 2016;10(2):2636-43. https://doi.org/10.1021/acsnano.5b07678

69. Méndez-Medrano MG, Kowalska E, Lehoux A, Herissan A, Ohtani B, Bahena D, et al. Surface modification of TiO2 with Ag nanoparticles and CuO nanoclusters for application in photocatalysis. J Phys Chem C. 2016;120(9):5143-54. https://doi.org/10.1021/acs.jpcc.5b10703

70. Fechine GJM, Christensen PA, Egerton TA, White JR. Evaluation of poly(ethylene terephthalate) photostabilisation using FTIR spectrometry of evolved carbon dioxide. Polym Degrad Stab. 2009;94(2):234-9. https://doi.org/10.1016/j.polymdegradstab.2008.10.025

71. Fechine GJM, Rabello MS, Souto-Maior RM. The effect of ultraviolet stabilizers on the photodegradation of poly(ethylene terephthalate) Polym Degrad Stab. 2002;75(1):153-9. https://doi.org/10.1016/S0141-3910(01)00214-2

72. Fechine GJM, Rabello MS, Souto-Maior RM, Catalani LH. Surface characterization of photodegraded poly(ethylene terephthalate). The effect of ultraviolet absorbers. Polymer. 2004;45(7):2303-8. https://doi.org/10.1016/j.polymer.2004.02.003 